\title{
The cost of government borrowing and yields on Croatian government bonds
}

\author{
ANTO BAJO Institute of Public Finance \\ MARKO PRIMORAC Faculty of Economics and Business Zagreb
}

The new borrowing of the Croatian government in 2013 has mainly been used for paying off the existing debt principal and interest. Receipts from borrowing have not been used for capital investment financing for quite a long time. High expenses for debt principal and interest repayment are due to huge budget deficits which increase credit risk and, consequently, raise borrowing costs and yields on government bonds. Reducing the deficit and public debt by 2016 is not included in the current government's fiscal consolidation plans, which could lead to further growth in yields on new government bond issues.

\section{PRINCIPLES OF MARKET-BASED GOVERNMENT DEFICIT FINANGING AND GOVERNMENT BOND YIELDS}

A budget deficit can be financed in several ways, e.g. through borrowing on the domestic or international markets. The government can borrow by raising loans or issuing securities: bonds and Treasury bills. Borrowing in the form of loans involves discretionary negotiation of the loan terms between the representatives of the government and banks. Compared with loans, borrowing via bonds is more transparent, because a large number of market participants assess the creditworthiness of the government and compete for the purchase of bonds.

Yield is the key motive for investors to invest in government bonds. In contrast to loans (where creditors only earn income from interest), buyers of government bonds can derive earnings from coupon interest (in the case of coupon bonds), but also from any difference between the purchase and the sales price of a bond. The yield actually represents total earnings of a bond buyer, consisting of interest and the price difference. A government bond yield can be expressed in a number of similar ways, the most frequently used among them being yield to maturity.

Yield to maturity (YTM) is the total yield of a bond expressed as an annual rate, provided that the bond is held till maturity, that coupon payments are reinvested and that return on investment equals the rate of return to maturity. By purchasing bonds, investors assume a risk on which the expected bond yield depends. The greater the assumed investment risk, the higher the expected yield (earnings). The deeper

\footnotetext{
${ }^{1}$ The nominal or coupon yield is the total annual amount of coupon (or interest) payments divided by the principal (the nominal price of a bond). The current yield is the total annual amount of coupon payments divided by the spot market price of a bond.
} 
the uncertainty of collection of claims (a country's credit risk), the higher the yield to maturity on government bonds. A change in a country's credit risk leads to changes in the supply of and demand for government bonds on financial markets. Changes in supply and demand result in changes in the prices of bonds, and given that yields directly depend, among other things, on prices, yields to maturity also change. The lower the price of bonds paid by an investor on the market, the higher the yields the investor can earn by holding the bonds to maturity.

\section{THE COST AND BORROWING CONDITIONS OF THE REPUBLIC OF CROATIA}

According to Government and Ministry of Finance estimates, the average general government deficit will remain above $4 \%$ of GDP, but according to Eurostat's calculations, it will be higher, 6\% of GDP from 2013 to 2015 (Chart I). From 2002 to 2012, the government borrowed between HRK I.5bn (in 2007) and HRK I6.5bn (in 2009). However, only in the first nine months of 2013, it borrowed HRK I8.Ibn. Public debt exceeded the level of $60 \%$ of GDP as early as 2013 and, by all odds, it could soar to $65 \%$ of GDP by 2016 (Chart 2).

Increased borrowing pushed up the annual interest expenses (from HRK 3.3bn in 2002 to HRK 8.3bn in 2OI2; in 2016, they are expected to reach almost HRK 13bn). In the absence of any major economic recovery, interest expenses are going to jump from $1.5 \%$ (in 2008) to a high of 3.5\% of GDP in 2016 (Chart 3). The amount of interest expenses has been fairly high: in some years, it even exceeded the amount of deficit. This means that the government takes out loans exclusively to cover the cost of its previous borrowing.

The assessment of borrowing costs requires complete information on loans and issued bonds. Regrettably, the available information only provides insight into the main characteristic of government borrowing through bond issues, while there are no data on loans.

Since gaining its independence, Croatia has borrowed by issuing bonds on the domestic and international financial markets, denominated in Croatian dinars, kuna, German marks, euros and US dollars, and, from 1999 to 2003, also in Japanese yens.

In the period 1991-2013, the government issued about 60 bonds on the domestic and international capital markets, for the financing of the national budget execution, refinancing of obligations, settlement of liabilities to the creditors of the Croatian Health Insurance Fund (CHIF), payment of savings deposits and creating of conditions for economic restructuring. In brief, receipts from borrowing through bonds have mainly been used for the financing of current expenditures, whereas loans were largely used for capital investment financing.

From 1991 to 2013, the average yield on bonds at issue was 5.58\%. The yield on the so-called Samurai bond, issued for budget execution financing in 2003, was the lowest, 1.23\%. This was by far the most favourable borrowing through bonds ever in Croatia. The highest yield of $7.4485 \%$ was earned on a bond issued on international capital markets in 1999.

The average maturity of the bonds was about 7.5 years. Bonds with the shortest maturities (I year) were issued in the early 1990s, and those with the longest maturities (Io years) during the 2000s. Worthy of note is that there were no bond issues in 1993, 1995 and 2008. In 2013, there are a total of 21 active bonds, of which 12 are listed on the domestic and international capital markets.

By 2024, a total of HRK II4bn in the principal of the debt arising from issued bonds will become due for payment by the government (Chart 4). The tradable debt structure by maturity is rather uneven. For example, principal amounts to become due will be HRK 3.5bn in 2016 and almost HRK I8bn in 20I7. Such strong refinancing pressures can shake investor confidence in the government's debt repayment capacity (e.g. in 2017), and, consequently, increase investors' assessment of Croatia's sovereign credit risk. This is 
sufficient reason for growth of the yields to maturity of Croatian government bonds due to the strong supply of, but weak demand for these bonds in the market, and, indirectly, a fall in their prices. An increase in yields on financial markets also places the country in an unfavourable negotiating position with regard to the conditions of off-market borrowing (from banks), which adversely affects the cost of borrowing (interest rates) as well.

\section{YIELDS ON SOVEREIGN BONDS OF THE REPUBLIC OF GROATIA}

Government bonds listed on the domestic financial market in 2013 amount to HRK 26.25bn and EUR 4.25bn (a total of EUR 7.7bn or HRK 58.6bn). ${ }^{2}$ Average yield per bond issue is $5.804 \%$. The latest bond issue on the domestic market dates from July 20I3. It was worth HRK 2.75bn and EUR 75om with maturities of 5 and II years. The coupon interest rate on outstanding bonds ranges between $4.25 \%$ and $6.75 \%$ and their prices from 97.IOI to the nominal amount of IOO (or from 97.10I\% to 100\% of the nominal amount). Various combinations of interest rates, prices and maturities resulted in different yields at issue of the bonds.

Table I

Active bonds issued on the domestic market

\begin{tabular}{|c|c|c|c|c|c|c|c|c|}
\hline $\begin{array}{l}\text { Bond } \\
\text { RHMF-O }\end{array}$ & $\begin{array}{l}\underset{\text { (in }}{\text { Amount }} \\
\text { millions) }\end{array}$ & Gurrency & $\begin{array}{c}\text { Interest } \\
\text { rate }(\%)\end{array}$ & $\begin{array}{c}\text { Price at } \\
\text { issue }\end{array}$ & $\begin{array}{l}\text { Yield } \\
\text { at } \\
\text { issue }\end{array}$ & Date of issue & $\begin{array}{c}\text { Maturity } \\
\text { date }\end{array}$ & $\begin{array}{l}\text { Number } \\
\text { of } \\
\text { coupon } \\
\text { payments }\end{array}$ \\
\hline I42A & 650 & EUR & 5.500 & 98.II9 & 5.750 & IO Feb. 2004 & IO Feb. 2014 & 2 \\
\hline I9BA & 500 & EUR & 5.375 & 99.655 & 5.409 & 29 Nov. 2004 & 29 Nov. 2019 & 2 \\
\hline $\mathrm{I} 57 \mathrm{~A}$ & 350 & EUR & 4.250 & 98.845 & 4.394 & I4 July 2005 & I4 July 2015 & 2 \\
\hline I5CA & 5,500 & HRK & 5.250 & 100.000 & 5.250 & I5 Dec. 2005 & I5 Dec. 2015 & 2 \\
\hline $\mathrm{I} 72 \mathrm{~A}$ & 5,500 & HRK & 4.750 & 98.748 & 4.910 & 8 Feb. 2007 & 8 Feb. 2017 & 2 \\
\hline $203 \mathrm{~A}$ & 5,000 & HRK & 6.750 & 98.575 & 6.950 & 5 March 2010 & 5 March. 2020 & 2 \\
\hline 2O3E & I,OOO & EUR & 6.500 & 98.559 & 6.700 & 5 March 2010 & 5 March 2020 & 2 \\
\hline $\mathrm{I7BA}$ & 4,000 & HRK & 6.250 & 98.998 & 6.430 & 25 Nov. 2010 & 25 Nov. 2017 & 2 \\
\hline $167 \mathrm{~A}$ & 3,500 & HRK & 5.750 & 99.I46 & 5.950 & 22 July $20 I I$ & 22 July 2016 & 2 \\
\hline $227 \mathrm{E}$ & $\mathrm{I}, \mathrm{OOO}$ & EUR & 6.500 & 97.IOI & 6.880 & 22 July $2 \mathrm{OII}$ & 22 July 2022 & 2 \\
\hline $187 \mathrm{~A}$ & 2,750 & HRK & 5.250 & 99.957 & 5.260 & IO July 2013 & IO July 2018 & 2 \\
\hline $247 \mathrm{E}$ & 750 & EUR & 5.750 & 99.919 & 5.760 & Io July, 2013 & IO July 2024 & 2 \\
\hline Average & & & 5.656 & 98.969 & 5.804 & & & \\
\hline Average in HRK & & & 5.667 & 99.237 & 5.792 & & & \\
\hline Average in EUR & & & 5.646 & 98.700 & 5.815 & & & \\
\hline
\end{tabular}

Source: Bloomberg (2013b).

Bonds listed on international markets amount to EUR 2bn and USD gbn (about HRK 65.5bn in total). The average yield at issue of the bonds is $6.265 \%$, ranging from $5.11 \%$ to $7,009 \%$. Differences in yields to maturity are due to not only different coupon interest rates, prices of bonds and their maturity dates, but also different ways of coupon interest payments which occur on an annual or semi-annual basis. For domestic bonds, coupons are paid on a semi-annual basis only, and for foreign bonds, a combination of annual and semi-annual payments is used.

\footnotetext{
${ }^{2}$ The conversion of the amounts of principal for bonds denominated in other currencies into kuna was based on the CNB's middle exchange rates in October 2013 (monthly average) of EUR/HRK 7.6I44I9 and USD/HRK 5.585714. These exchange rates are also referred to later in this article.
}

NEWSLETTER 83 | A. BAJO \& M. PRIMORAC | The cost of government borrowing and yields on... I Institute of Public Finance 3 
Table 2

Active bonds issued on international financial markets

\begin{tabular}{|c|c|c|c|c|c|c|c|c|}
\hline Euro bond & $\begin{array}{l}\underset{\text { Amount }}{\text { in }} \\
\text { millions })\end{array}$ & $\begin{array}{c}\text { Gurrenc } \\
y\end{array}$ & $\begin{array}{c}\text { Interes } \\
\text { t rate } \\
(\%)\end{array}$ & $\begin{array}{l}\text { Price at } \\
\text { issue }\end{array}$ & $\begin{array}{l}\text { Yield at } \\
\text { issue }\end{array}$ & Date of issue & $\begin{array}{l}\text { Maturity } \\
\text { date }\end{array}$ & $\begin{array}{c}\text { Number of } \\
\text { coupon } \\
\text { payments }\end{array}$ \\
\hline VI & 500 & EUR & 5.000 & 99.I55 & 5.IIO & I5 April 2004 & I5 April 2014 & I \\
\hline VII & 750 & EUR & 6.500 & 99.675 & $6.57 \mathrm{I}$ & 5 June 2009 & 5 Jan. 2015 & $\mathrm{I}$ \\
\hline I & $\mathrm{I}, 5 \mathrm{OO}$ & USD & 6.750 & 98.160 & 7.009 & 5 Nov. 2009 & 5 Nov. 2019 & 2 \\
\hline II & 1,250 & USD & 6.625 & 99.IO2 & 6.750 & I4 July 2010 & I4 July 2020 & 2 \\
\hline III & $\mathrm{I}, 5 \mathrm{OO}$ & USD & 6.375 & 98.250 & 6.617 & $\begin{array}{r}24 \mathrm{March} \\
2 \mathrm{OII} \\
\end{array}$ & $\begin{array}{r}24 \mathrm{March} \\
2 \mathrm{O} 2 \mathrm{I} \\
\end{array}$ & 2 \\
\hline VIII & 750 & EUR & 5.875 & 98.600 & 6.127 & 8 July $20 I I$ & 9 July 2018 & $\mathrm{I}$ \\
\hline IV & 1,500 & USD & 6.250 & 99.472 & 6.375 & 27 April 2012 & 27 April 2017 & 2 \\
\hline V & $\mathrm{I}, 500$ & USD & 5.500 & 99.054 & 5.625 & 4 April 2OI3 & 4 April 2023 & 2 \\
\hline IX & $\mathrm{I}, 750$ & USD & 6.000 & 98.488 & 6.203 & 26 Nov. 2013 & 26 Jan. 2024 & 2 \\
\hline Average & & & 6.097 & 98.884 & 6.265 & & & \\
\hline Average EUR & & & 5.792 & 99.I43 & 5.936 & & & \\
\hline Average USD & & & 6.250 & 98.754 & 6.430 & & & \\
\hline
\end{tabular}

The latest bond issue on international markets worth USD 1.75bn reflects, to a large degree, investor expectations about Croatia's sovereign credit risk movements. Yield on that issue was as much as $0.578 \%$ higher than the yields on bond issues with similar characteristics (two issues worth USD I.5bn each) that appeared about half a year earlier. Although market conditions should also be taken into account in the assessment of borrowing costs, the growth in yields on US dollar bonds shows a deterioration of investor perception of the Republic of Croatia's creditworthiness.

Yields on sovereign bonds issued on the domestic capital market are $0.461 \%$ lower on average than yields on bonds issued on international markets. Domestic bond issues are more favourable on average for the government, due to lower risk. Specifically, a half of the total amount of bonds issued on the domestic market is in kuna, which reduces the currency risk (as the national budget revenues are also derived in kuna).

The costs of borrowing through kuna and euro bonds are the lowest borrowing costs on average for the government. The average yield on six active kuna bonds is $5.792 \%$. The average yield on nine eurodenominated bonds (six domestic and three foreign bonds) stands at 5.856\%, and the yield on six foreign bonds in US dollars is $6.43 \%$. A simple calculation shows that yields on kuna bonds are lower than on euro bonds by $0.064 \%$, and lower than on US dollar-denominated bonds by as much as $0.638 \%$.

Worth noting is that the government also used currency swap in at least four (out of six) issues of foreign US dollar-denominated bonds, in order to reduce the risk of a change in a currency's exchange rate (currency risk). However, the government used currency swaps to hedge against changes in the exchange rate of the dollar against the euro, but not against the kuna (in which its revenues are denominated). This is probably due to investors' unwillingness to assume the risk of changes in the kuna exchange rate (or to a fairly high price of insurance against such a risk). Currency swaps have certainly increased the cost of government borrowing in US dollars. Regrettably, due to a lack of publicly available information on the details of currency swap contracts, it is impossible to establish the total cost of borrowing through US dollar-denominated bonds.

The Republic of Croatia has structured kuna and euro-denominated yield curves (Charts 5 and 6). The forms of these curves are normal, which means that yields grow as maturities increase. The Government of the Republic of Croatia should, in its future bond issues, continue trying to complement and extend 
the yield curves. For the kuna yield curve, a bond should be issued with maturity in mid-2019 and after 2020. For the euro yield curve, there are no data on yields on debt maturing in 2017 or 2018. Should the burden of liabilities falling due in the above mentioned years be too heavy for the state budget, then bond issues should not be large. For the financial market development, a larger number of small bond issues with different maturities represent a better solution than a small number of issues involving large amounts of liabilities.

\section{YIELDS ON SOVEREIGN BONDS OF THE REPUBLIC OF CROATIA AND OTHER EU MEMBER STATES}

The Maastricht Treaty lays down five convergence criteria that must be met by EU member states if they wish to adopt the euro. One of them is maintaining long-term interest rates - average yields on ten-year government bonds in the previous year - at a level not exceeding by more than $2 \%$ the non-weighted arithmetic mean of yields on similar ten-year bonds in three EU member states with the lowest inflation rate. ${ }^{3}$ As a result, yields on sovereign bonds of EU member states started to converge in 1993 and have been almost fully converged since May 2000, at a level below 5\% (Chart 7). Yields on long-term bonds of certain countries (e.g. Greece) were fairly high even before the crisis. However, with the accession of these countries to the EU and, particularly, with their adoption of the euro, numerous risks for investors (creditors), such as political, currency and other risks, have receded markedly or even disappeared. Therefore, investors offset potential differences in yields by trading, which was particularly evident in the period 2000-2007.

In an environment of fiscal instability, investors have become risk sensitive, which makes even the smallest differences in stability across countries extremely important. Thus, since 2008, there has been a sharp divergence in terms of yields on sovereign bonds among the EU member states, due to different investor assessments of the financial perspectives and credit risk of these countries. While all EU member states are hit by the crisis, it has had different impacts on their fiscal positions. Investors have increased their investments in sovereign bonds of the countries that were comparatively more resistant to the effects of the crisis, which affected the prices of bonds (reflecting the supply-demand ratio) and, consequently, led to a decrease in yields on safer bonds and an increase in yields on the bonds of riskier EU member states. The most obvious examples are yields on the sovereign bonds of Greece which, due to the risk of bankruptcy, surged to almost 30\%. Investors sold off bonds in order to recover at least part of the invested funds. During the restructuring of their portfolios, investors used to buy bonds of the safest countries (primarily Germany), the yields on which declined (due to growing demand). German bonds (popularly known as Bunds) have almost continuously had the lowest and most stable yields. These yields are also used as benchmark (risk-free) yields in Europe, whereas yields of other countries are determined at a premium on German bond yields.

Since 2010, Eurostat has carried out statistical monitoring of sovereign bonds of the Republic of Croatia. Compared with other EU member states, Croatia is among higher credit risk countries (Chart 7). According to the amount of yields, it belongs to the group of Mediterranean countries including Ireland, i.e. the countries severely hit by the financial crisis. This has been recognised by investors who therefore require higher yields on the bonds. Yields on sovereign bonds of the RC are similar to those of Italy and Spain. If the government does not assume a more active role in the management of government finance and public debt, there will be a risk of further growth in borrowing costs and yields on government bonds.

Yields on sovereign bonds of the Republic of Croatia are above the EU average (Chart 8). As expected, they are considerably higher than long-term yields on German bonds, but still markedly lower than yields on Greek bonds. As Croatia approached the EU, yields on its sovereign bonds converged with those on German bonds. However, after the outbreak of the financial crisis, the yields diverged and the difference between (the range of) yields on Croatian and German bonds expanded. This was due to an increase in

${ }^{3}$ For this purpose, the Harmonised Index of Consumer Prices (HICP) is used as a measure of inflation.

NEWSLETTER 83 | A. BAJO \& M. PRIMORAC | The cost of government borrowing and yields on... I Institute of Public Finance 5 
the relative country risk of Croatia from that of Germany. Nevertheless, unlike in most countries where yields have trended downwards, yields on Croatian bonds have gone up.

\section{CROATIA MUST GUT ITS BORROWING GOSTS}

The accession of the Republic of Croatia to the EU has had a positive impact on the borrowing costs. Had Croatia not become a member state, its debt costs would have probably been even higher. The potential entry of the country into the EMU and adoption of the euro as the official currency would certainly result in further reductions of debt costs (due to the elimination of the currency risk). As a consequence of the high government deficit and debt levels in Croatia, the European Commission will open an Excessive Deficit Procedure (EDP). This will be another call for caution for investors, which will probably lead to an increase in government bond yields and, consequently, in the cost of borrowing. On the other hand, undergoing an EDP is a kind of a "purgatory" after which yields may decline considerably due to compliance with EU fiscal rules. This in turn can have positive effects on credit risk. Should Croatia, while undergoing the EDP, strictly follow the rules and cut its deficit below 3\% of GDP, this could easily result in lower yields on government bonds and borrowing costs in general. Therefore, the Government of the Republic of Croatia should, as soon as possible, propose effective and reasonable measures to cut budget deficit, with a view to preserving, in the short run, the current level of investor confidence.

The Ministry of Finance's Sector for Public Debt Management deserves to be commended for creating a yield curve of its bond issues so far, and improving the adjustment of the public debt maturity structure. Such prudential measures underpin the development of the domestic financial market and government finance management. However, there is still much room for improvement in the debt maturity structure (i. e. alignment of the debt maturity schedule) for the purpose of and equitable distribution of the debt repayment burden.

\section{RECOMMENDATIONS}

The Government and Ministry of Finance could significantly reduce the cost of borrowing and the country's exposure to credit risk by introducing a couple of technical measures:

The government could again try its luck by issuing new bonds on the Asian markets (primarily in Japan and China). These are markets with higher risk appetite, so that the total borrowing costs are likely to be lower than elsewhere, even including the currency risk protection costs.

Croatia should borrow on the domestic capital market, by offering institutional investors a larger number of bonds of lower nominal values. Despite the relatively tough austerity measures, it is unlikely that the government will issue savings bonds and sell them to citizens. The main reasons for that are low Government credibility and a general lack of confidence among the population due to the Government's poor financial management and inadequate reform measures.

The Ministry of Finance should participate more actively in the market, by redeeming bonds in case of a price fall and by refinancing more expensive debts from cheaper sources of financing occasionally available on the market.

The Government and Ministry of Finance should provide better and more extensive information to investors, but also the wider interested public, on the stock and structure of debt. So far, the Ministry has published only two documents on this particular issue: an Annual Report on and Strategy of Public Debt Management (in 2006) and a Public Debt Management Strategy for the period 20II-13 (in 201I). Besides being published at irregular intervals, these documents do not provide all the relevant data. 
Improvements should be made in data on the non-tradable portion of public debt (loans). Due to a lack of detailed information on loans taken out, investors and the wider interested public have no insight into the actual borrowing conditions or the maturity structure of the loans. This puts on restraints on foreign investors as well, because bond issue prospectuses do not provide them with credible information on public debt, which further increases the investment risk and expected yield.

The Ministry of Finance should publish, on a regular basis, an issuance calendar of T-bills (the last such calendar is available for 20II), and a planned bond issuance calendar (the last one available relates to 2007). The publication of the issuance calendars would enable potential investors to manage their own assets and liabilities structure in a more efficient way, which could result in further reductions of required yields.

The government should urgently improve the institutional and administrative frameworks of public debt management, by passing a separate Public Debt Act, but also by setting up a separate Public Debt Management Agency capable of performing the tasks entrusted to it in a more effective way.

\section{ANNEX}

\section{Chart I}

General government deficit, 2009-2016 (\% of GDP)

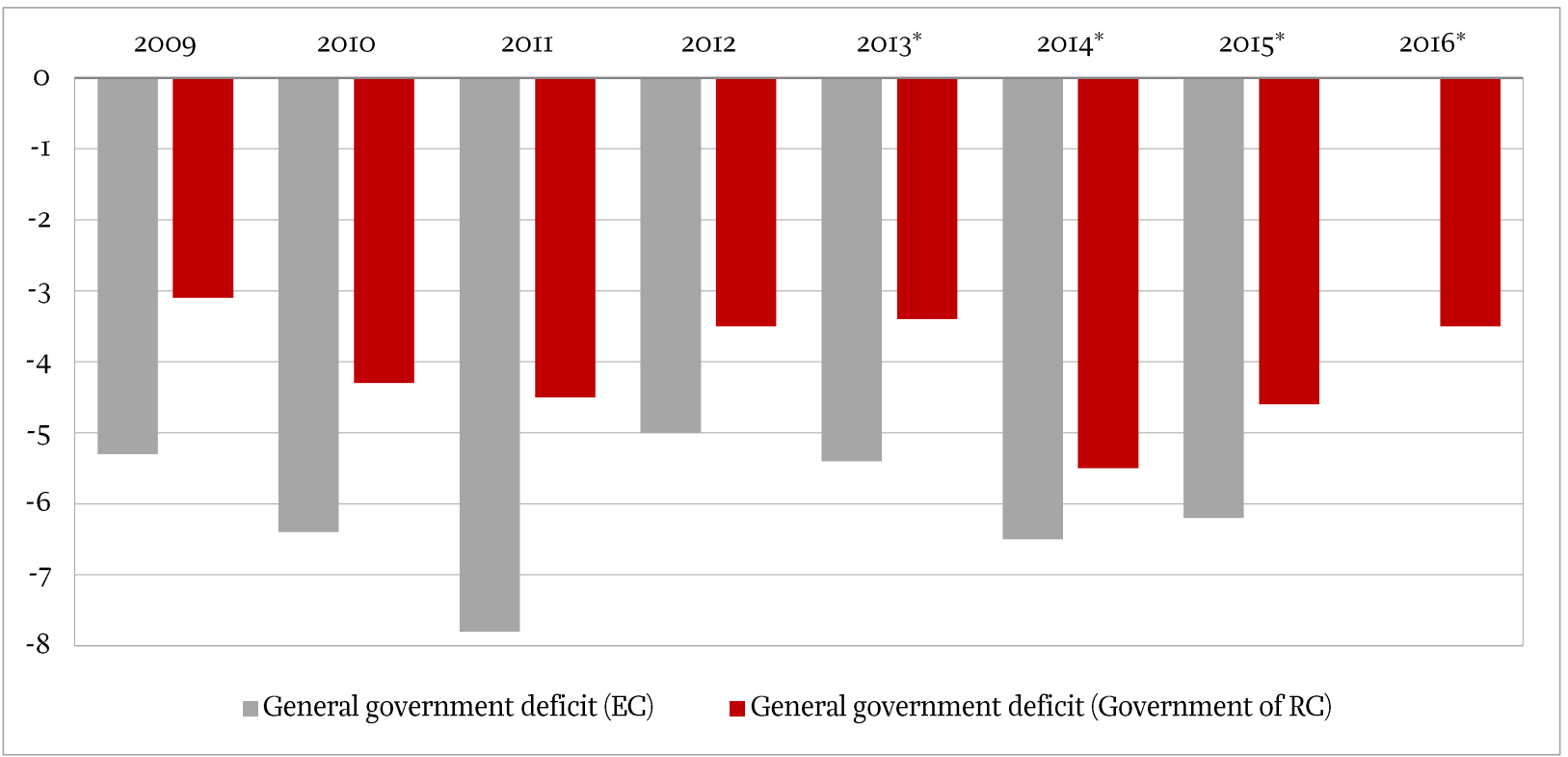

*projected values

Sources: Ministry of Finance (2013b) and Eurostat (2013). 


\section{Chart 2}

General government debt, 2009-20I6 (\% of GDP)

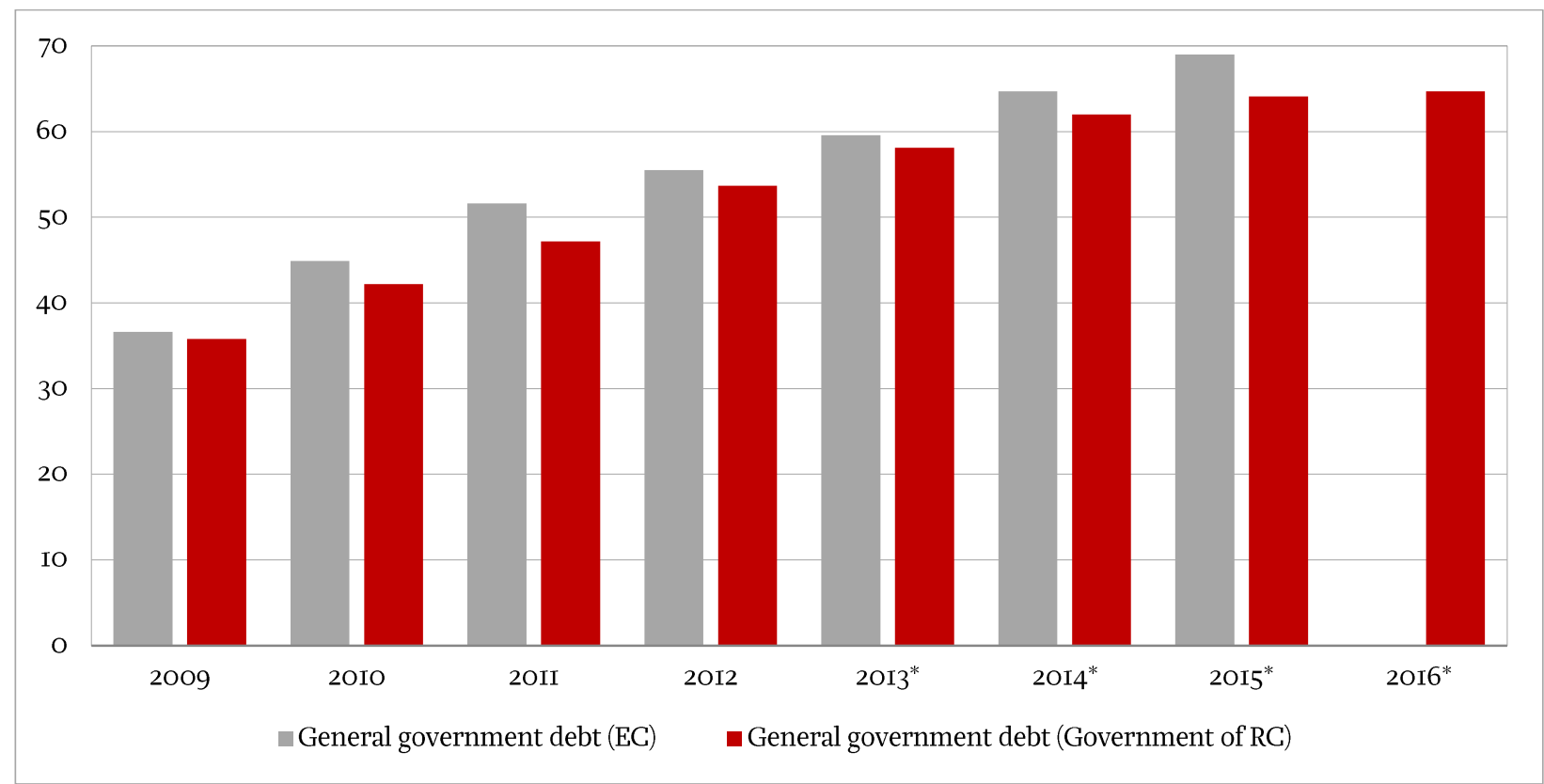

* projected values

Sources: Ministry of Finance (2013a) and Eurostat (2013).

\section{Chart 3}

Interest expenses, 2002-2016 (in billion HRK and as a \% of GDP)

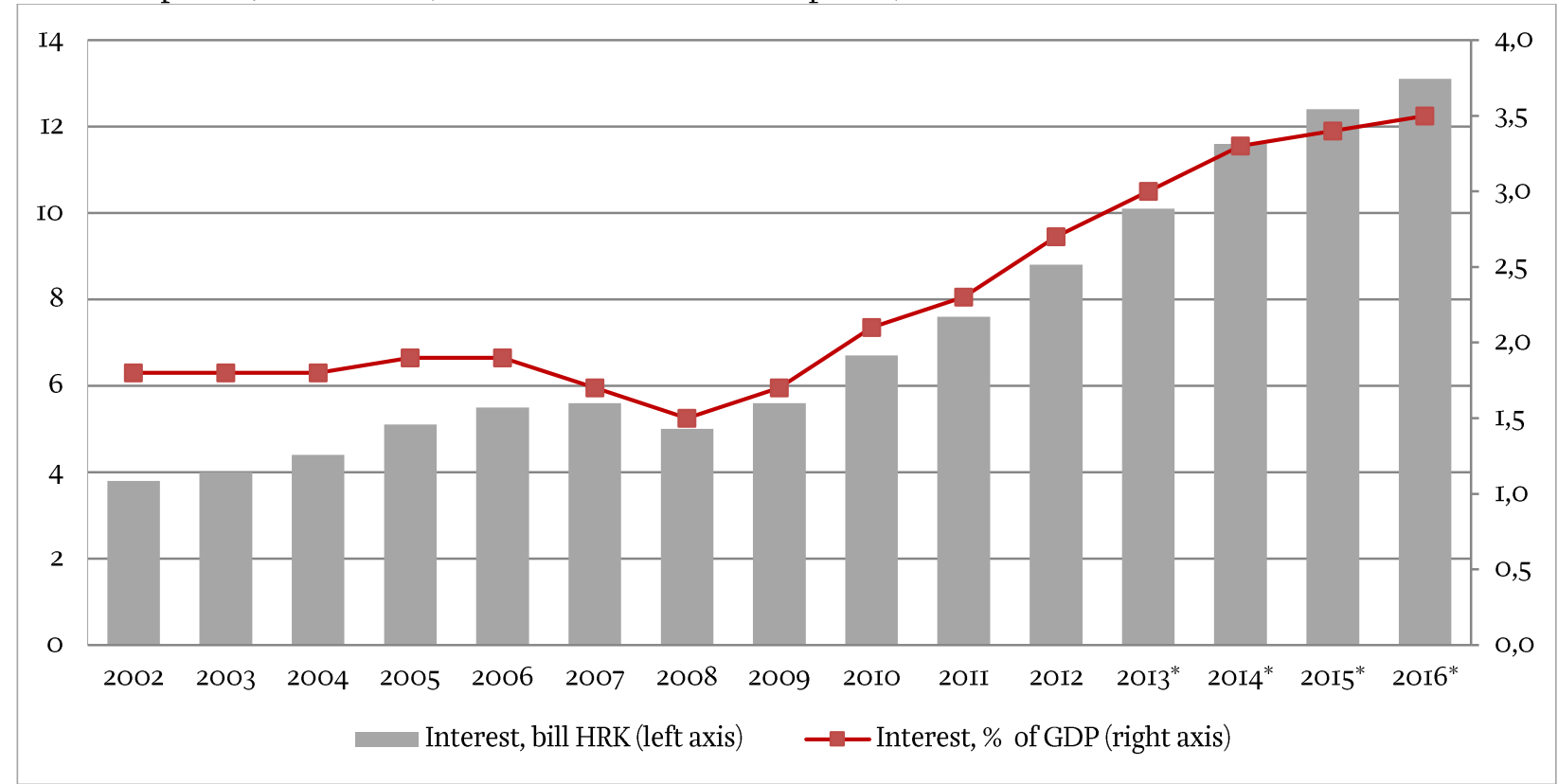

Sources: Ministry of Finance (2013a). 


\section{Chart 4}

Bond maturity projection through 2024 (in billion HRK)

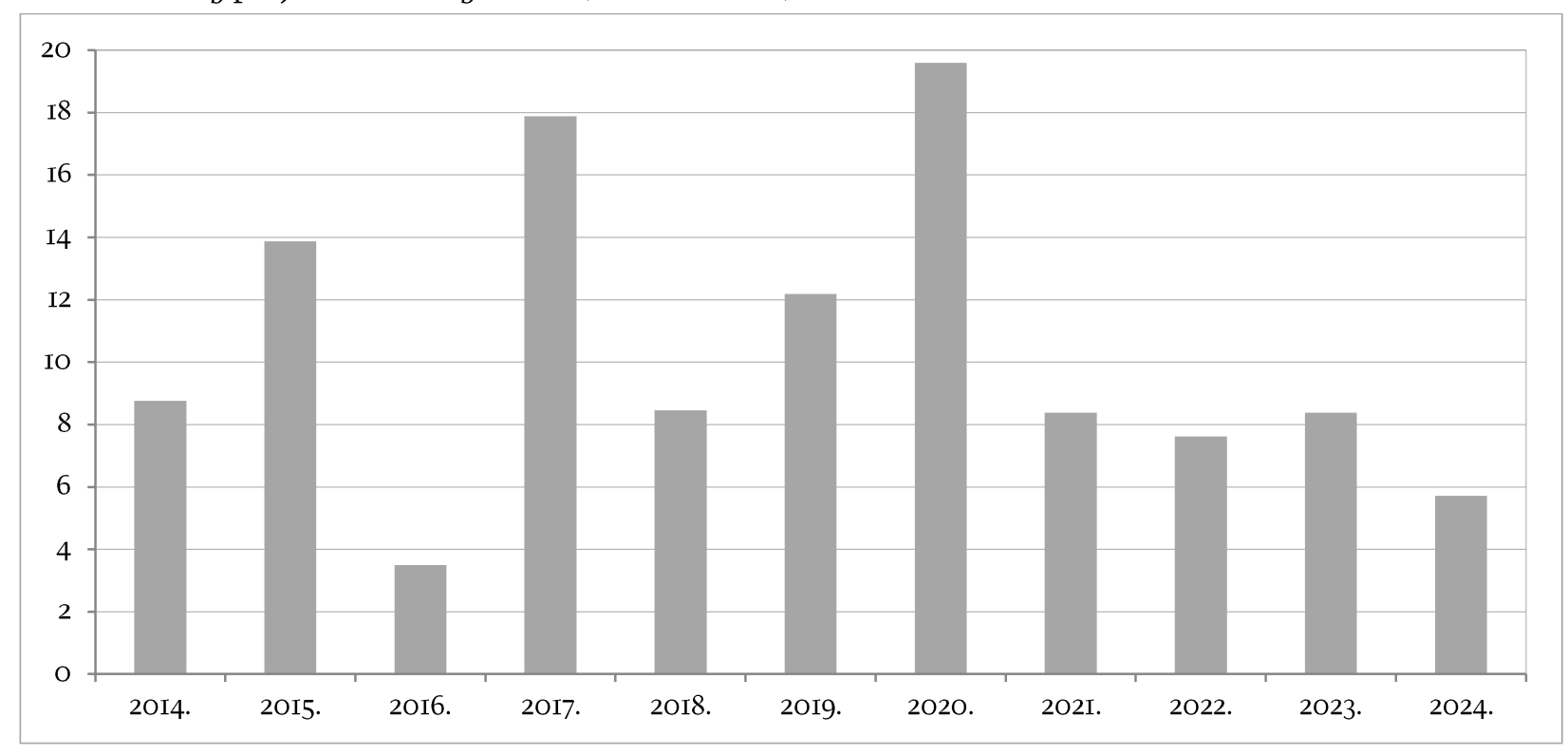

Note: The conversion of the principal amount of bonds denominated in other currencies into kuna was made using the middle exchange rates of the kuna in October 2013 (monthly average) of EUR/HRK 7.6I44I9 and USD/HRK 5.5857I4.

Source: Authors' calculation based on the Ministry of Finance data.

\section{Chart 5}

Yields to maturity on sovereign kuna-denominated bonds of the $R C$, issued on the domestic market on 22 October $2013(\%)$

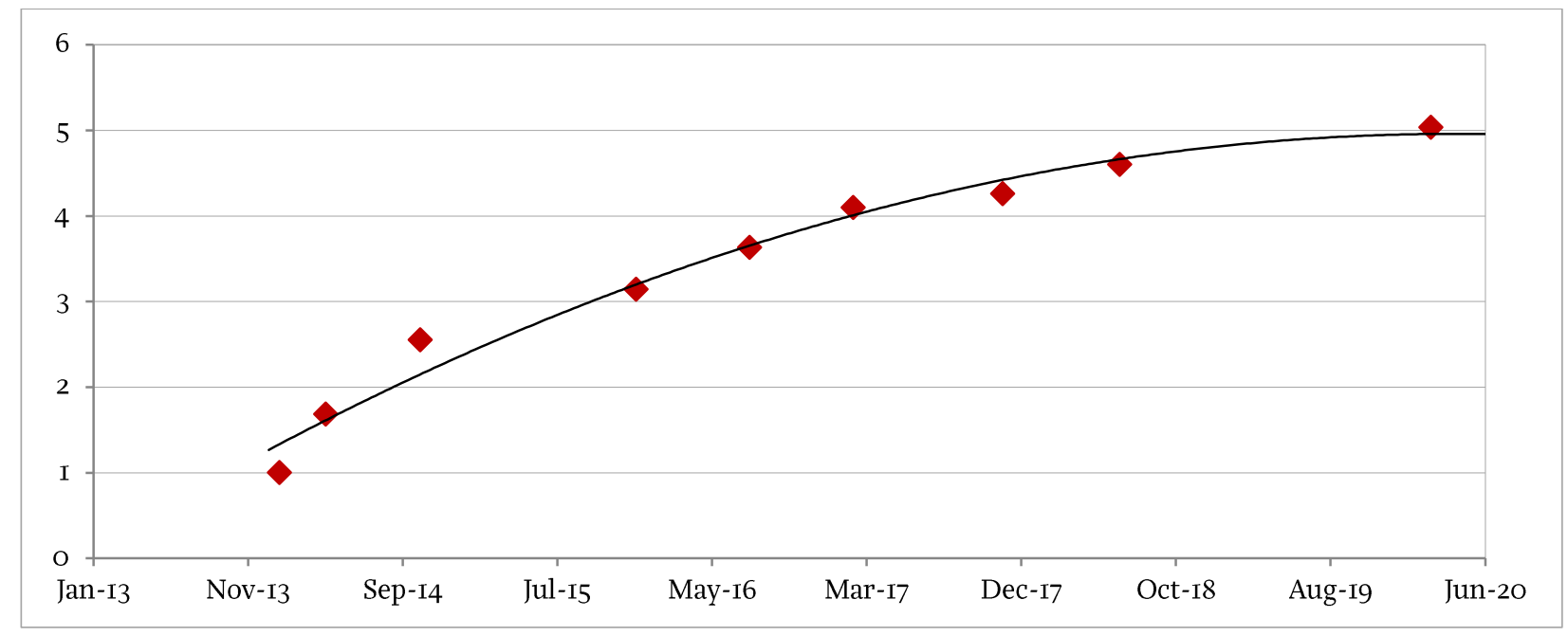

Source: Bloomberg (20I3b). 


\section{Chart 6}

Yields to maturity on sovereign euro-denominated bonds of the RG, issued on the domestic market on 22 October 2013 (\%)

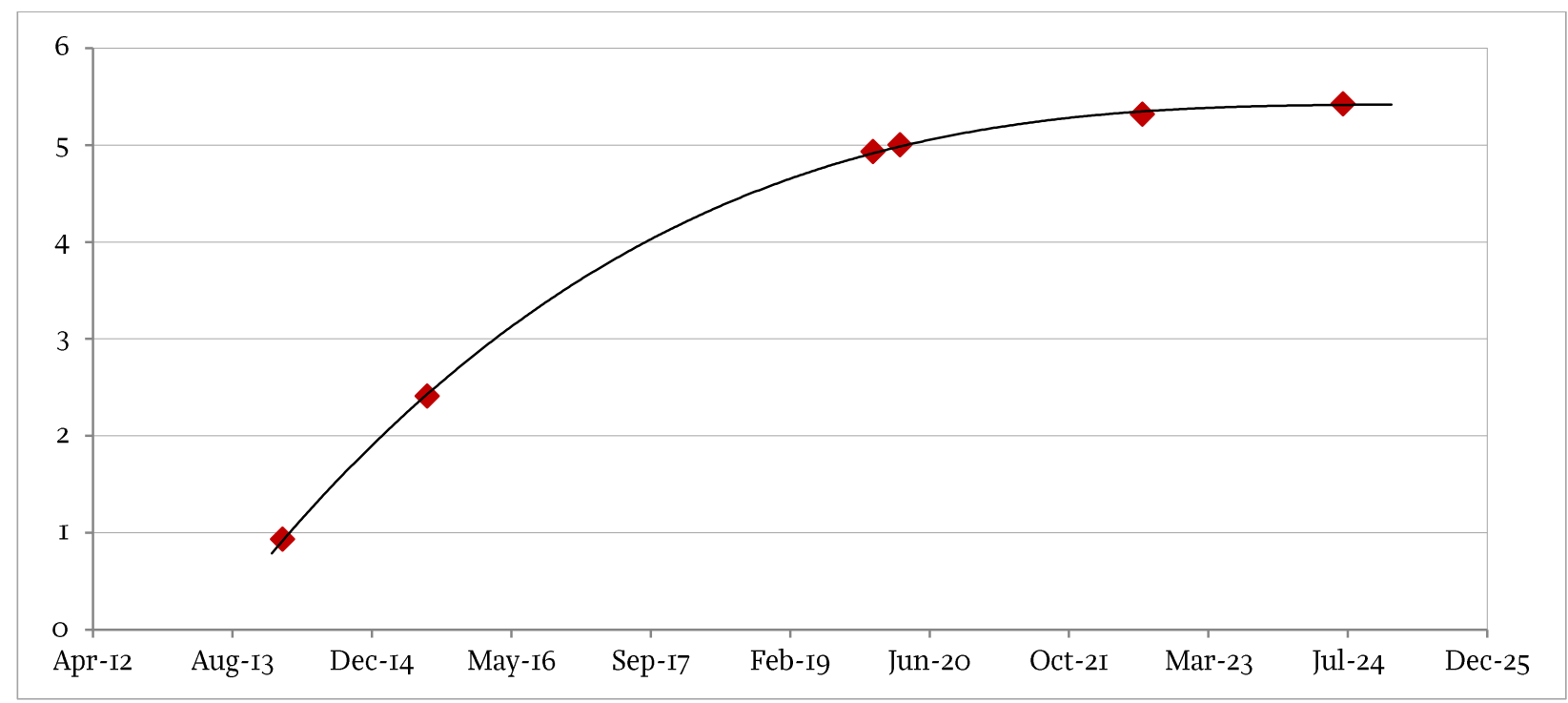

Source: Bloomberg (2013b).

\section{Chart 7}

Yields on long-term bonds of selected EU member states, 1993-2013 (\%)

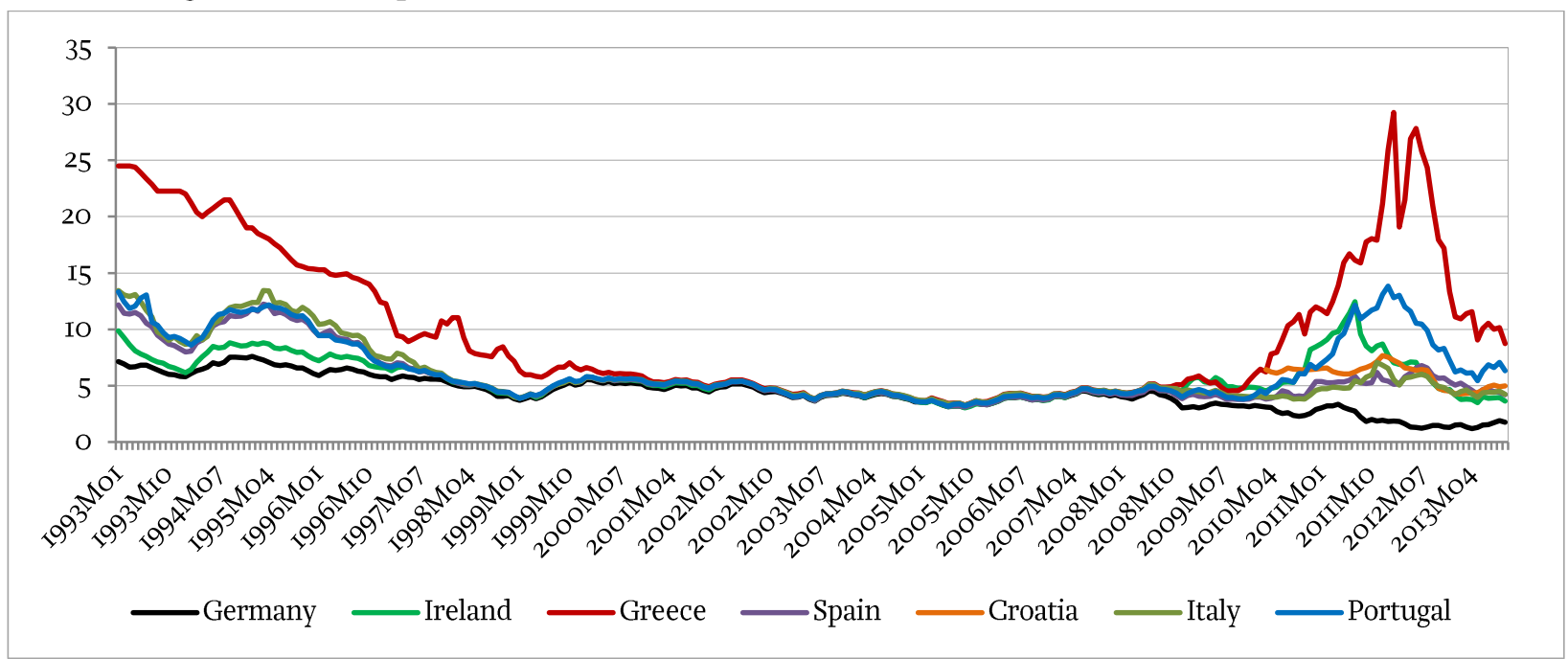

Note: Long-term yields on sovereign bonds have been calculated as monthly averages. They relate to yields on secondary market sovereign bonds with a remaining maturity of about Io years. A bond or bonds (in the portfolio) are regularly replaced in order to avoid potential maturity disturbances. This definition is also used in the context of the European Economic and Monetary Union's convergence criteria, in terms of uniformity of long-term interest rates. The data for the Republic of Croatia have been available only since March 2010.

Source: Eurostat (20I3). 


\section{Chart 8}

Movements in yields on sovereign bonds in the EU, Greece, Croatia and Germany (\%)

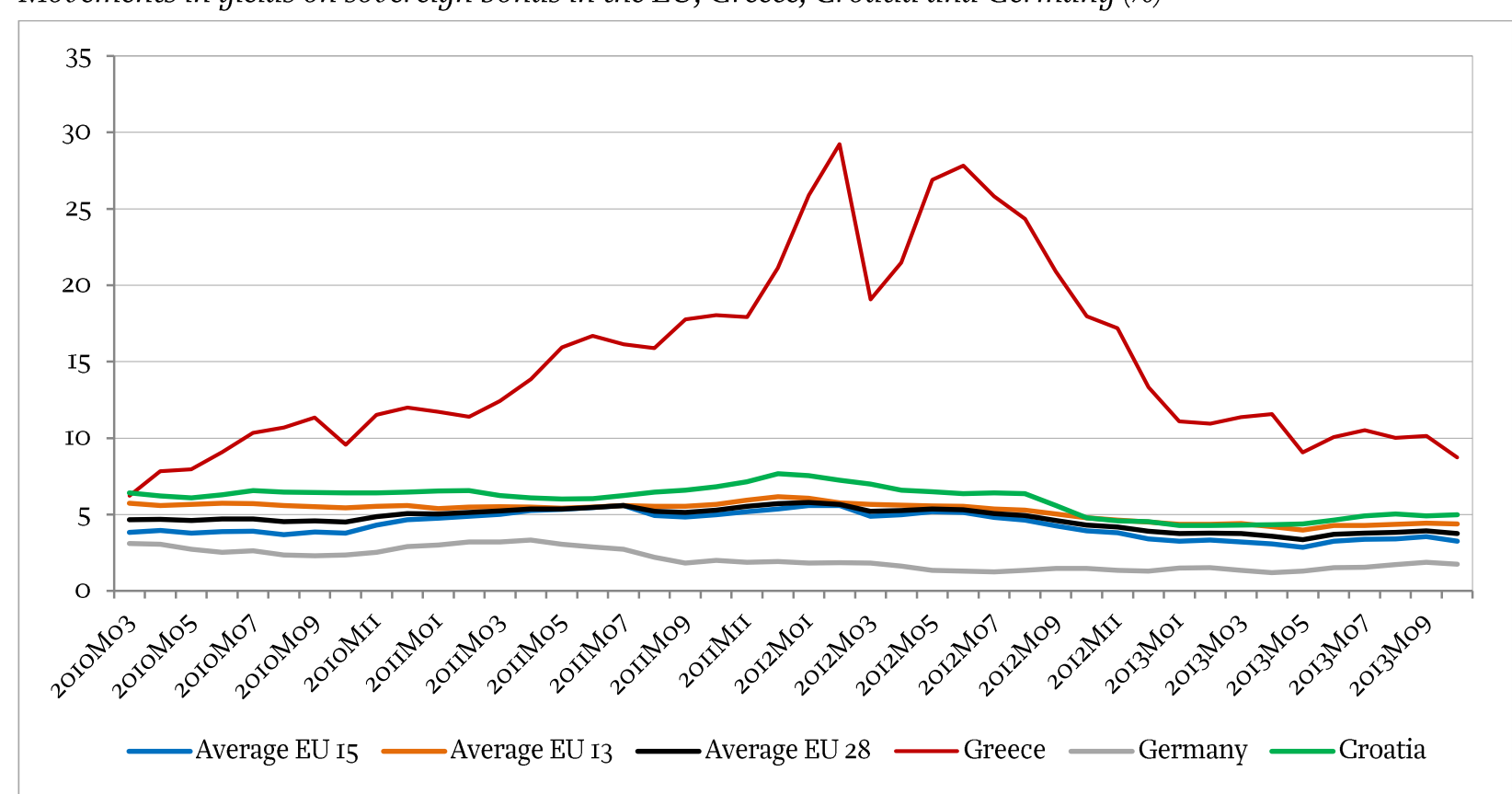

Note: See Note below Chart 7 .

Source: Eurostat (2013).

\section{LITERATURE}

Bajo, A., Primorac, M. and Andabaka Badurina, A., 20II. Osnove upravljanja javnim dugom. Zagreb: Institute of Public Finance.

Bloomberg, 2013a. European Debt Crisis.

Bloomberg, 2013b. World market-bonds.

Ehrmann, M. [et al.], 2007. Convergence and Anchoring of Yield Curves in the Euro Area. European Central Bank, Working paper No. 8I7.

European Commission, 2013. Report from the Commission - Croatia. Report prepared in accordance with Article 126(3) of the Treaty, Brussels, 15.11.2013.

Eurostat, 2013. Long term government bonds yield.

Ministry of Finance, 20I3a. Obrazloženje prijedloga Državnog proračuna za 20I4. Zagreb: Ministry of Finance of the RC.

Ministry of Finance, 2013b. Time series data - Consolidated general government January-September 2013. Zagreb: Ministry of Finance of the RC. 